\title{
Pre-Stressed Concrete Box Girder Multi Cell (3-Cell) Bridge of Different Shapes a Comparative Study: A Review Paper
}

\author{
Selvan $\mathrm{V}^{1}$ and Gobinath $\mathrm{RS}^{2}$ \\ 1Department of Civil Engineering, Kumaraguru College of Technology, India \\ ${ }^{2}$ Department of engineering science, Kumaraguru College of Technology, India \\ *Corresponding author: Selvan V, Department of Civil Engineering, Kumaraguru \\ College of Technology, Coimbatore-641049, India, E-mail: vsaerosrec@gmail.com
}

\section{Review Article}

Volume 4 Issue 3

Received Date: November 19, 2019

Published Date: December 03, 2019

DOI: $10.23880 /$ nnoa-16000167

\section{Abstract}

A bridge may be a structure providing passage over Associate in nursing obstacle while not closing the means below. The required passage is also for a road, a railway, pedestrians, a canal or a pipeline. Now a days, bridge deck section of Box shapes are used widely. Most of the bridges made ar of Box girders. Method of post-tensioning within the construction of bridges is extremely common nowadays. Most of the bridges area unit of prestressed sorts (mostly post-tensioned). In this work, a trial was created to comparative study the various shapes of PSC box beam Multi Cell Bridge exploitation CSI Bridge (V-2017). Loading of IRC Class-A is applied and analysis is completed exploitation IRC 112 (2011).

Keywords: Box Girder; CSI Bridge (V-2107); Post-tensioned Bridge; IRC-112(2011); IRC Class-A Loading

\section{Introduction}

The continued enlargement of route network throughout the globe is basically the results of nice increasing traffic, population and intensive growth of metropolitan urban areas. This growth has cause several changes within the use and development of assorted varieties of bridges. As Span will increase, dead load is an important increasing factor. To reduce the load, unnecessary material, which is not utilized to its full capacity, is removed out of section, this ends up in the form of box beam or cellular structures, depending upon whether or not the shear deformations may be neglected or not. "When tension flanges of longitudinal girders area unit connected along, the resulting structure is called a box girder bridge". Span range is more for box bridge beam as compare to T-beam beam Bridge leading to relatively lesser range of piers for constant natural depression breadth and therefore ends up in economy. A box girder is formed when two web plates are joined by a common flange at both the top and the bottom. The closed cell which is formed has a much bigger torsional stiffness associate degreed strength than an open section and it's this feature that is that the usual reason for choosing a box girder configuration.

\section{Literature Review}

According to Actor Burdet, et al. [1] the paper presents the findings of the watching of the long-run deflections of 3 bridges that were retrofitted with external posttensioning. The bridges area unit main road prestressed concrete box-girder bridges designed by the balanced cantilever technique and retrofitted with further exterior post-tensioning cables for deflection management. It is shown that external post-tensioning may be a self-made 


\section{Nanomedicine \& Nanotechnology Open Access}

retrofitting technique for bridges with serviceability limit state problems. The rumored examples additionally highlight the worth of future monitoring of concrete bridges for the assessment of bridges, and for the look of retrofitting theme [2].

This paper presents associate degree analysis of flexural live-load distribution factors for a series of 3 span prestressed concrete girder bridges. The response of 1 bridge, measured throughout a static live-load check, was wont to assess the dependability of a finite-element model theme. Twenty-four variations of this model were then used to assess the procedures for computing flexural live-load distribution factors that area unit embodied in 3 bridge style codes. The finite-element models were additionally wont to investigate the effects that lift, intermediate diaphragms, end diaphragms, continuity, skew angle, and load type have on distribution factors.

A detailed modelling strategy of the bridge exploitation frame elements, shell elements, and rigid constraints accurately reproduced the moments calculated from strains measured throughout a live-load check. The calculated most middle span moment for every beam was inside 6 June 1944 of the measured moment.

Distribution factors calculated for lane loading were systematically not up to those calculated for truck loading, the average decrease was $10 \%$ [3].

The use of high hardening temperatures throughout fabrication affects the extent of prestress as a result of the strand length is fixed during the heating, the coefficients of thermal expansion of steel and concrete take issue, and the concrete temperature distribution may not be uniform. For the girders mentioned here, these effects combined to reduce the calculated prestressing stress from the original design values at release by 3 to $7 \%$, to scale back the initial camber by twenty six to fourhundredth, and to increase the bottom tension stress in service by 12 to $27 \%$. The main impact of applying the quality service temperature profiles to the bridge was to extend rock bottom stress by hour of the allowable tension stress [4].

This paper introduces the institution and simplification of the temperature field and also the general calculation methodology of temperature stress of the prestressed concrete box girders. Three varieties of sunshine gradient models were loaded to a true bridge severally, and got stress and displacement curves.
Research information of many prestressed concrete box girders was chosen from completely different regions of China to check the relative error of the calculated and measured worth [5].

This study has conferred the comparison of the overall space of steel beam and prestressing force needed within the cables, and stresses within the deck block mistreatment varied span lengths and girder spacing's. The result concludes that 4-girder system is found to be useful and economical in bridge style as compared to 5girder system for all the span length bridges [6].

This paper presents the investigation on many style aspects of post-tensioned box beam bridges designed by LRFD Specifications mistreatment typical or HighStrength Concrete (HSC). A pc program application was specially developed for this investigation. Cost evaluation of superstructures with totally different geometrical and material configurations has semiconductor diode to the event of optimum style charts for these types of superstructures. Variables wont to develop these charts embody, among others, span length, section depth, web spacing, tendon profile, and concrete strength. It was observed that HSC enables the action of considerably longer span lengths and/or longer net spacing that's not achievable when using normal strength concrete [7].

The aim of gift work is to match the political economy and structural behaviour of the ferroconcrete and prestressed concrete beams and looking for the quality of every. Results show that overall flexural behavior of prestressed concrete beam is incredibly smart all told facet compared to ferroconcrete beam. The result concludes that, the casting of precast prestressed beams is feasible with the designed mould. The moment of resistance showed by the equivalent prestressed beam as compared to the R.C.C. beam was more by $12.4 \%$. The moment inflicting cracking of the concrete just in case of prestressed beam was three times more than for equivalent reinforced beam. The ultimate deflection in case of prestressed beam was $60 \%$ but the final word deflections just in case of ferroconcrete beam [8].

RCC T-beam and Box girder of $25 \mathrm{~m}$ span length is considered in this work. IRC loading of sophistication A is applied in structure and analysis is finished mistreatment STAAD professional. Dead load calculations are done manually. Analysis is completed in each the cases. It is discovered that the service burden bending moments and Shear force for T-beam beam square measure lesser than 


\section{Nanomedicine \& Nanotechnology Open Access}

two cell Box Girder Bridge. Moment of resistance of steel for each has been evaluated and conclusions drawn that T-Beam beam has additional capability for twenty five $\mathrm{m}$ span. Shear force resistance of T-Beam Girder is additional compared to 2 cell box beam for twenty five $\mathrm{m}$ span. Cost of concrete for T-Beam Girder is less than 2 cell box beam as amount needed by T-beam beam. Quantity of steel for T-beam Girder is a smaller amount therefore value of steel in T-Beam is a smaller amount as compared to 2 cells box beam Bridge. For $25 \mathrm{~m}$ span, T-Beam beam is additional economical however if span is over twenty five $m$, so Box Girder is always suitable. This type of Bridge lies within the high tensional rigidity out there owing to closed box section.

This paper discusses a case study of a PSC beam that developed early injury to the deck due to the poor placement of concrete at the time of construction as established by in place non-destructive and core tests [9]. This paper reports a case study of the structural rehabilitation of the broken deck of a PSC box girder roadover bridge (ROB) for traffic over railway tracks. Strengthening of the deck was performed by putting in a series of steel joists at the bottom of the deck block and adding a skinny overlay of concrete at the highest to revive it to the requisite strength.

In this gift study, cost analysis and design of prestressed concrete girder is presented, the analyse and design of concrete girder is done by soncidering an IRC class $70 \mathrm{R}$ loading [10]. Software STAAD PRO is used for the analysis and style of prestressed concrete girders. Before using the software for analysis it will be valid by comparison its results with the corresponding classical theory result. In this study it's discovered by extracting result it's terminated that beam |box beam|beam $\}$ is costlier than I girder. It has additionally seen that losses is a lot of in I beam as compared to beam.

In this work, a serious bridge having 299 mts span, 36 no's of PSC Beams \& 8 no's of RCC Beams is taken into consideration [11]. Its main try is on PSC Beams, where the Beam post tensioning values, rate of elongation \& behavior can be defined after stressing. The main code that it follow during this course is IS: 1343 - 2012. The title is Code of Practice for Pre-stressed Concrete.

The result concludes that Bending moments and Shear force for PSC T-beam girder are lesser than RCC T-beam Girder Bridge. Shear force resistance of PSC T-Beam
Girder is more compared to RCC T- Girder for $24 \mathrm{~m}$ span [12].

The hysteretic behavior and seismic characteristics of the prestressed concrete bridge pier were researched in this word. The effects of the prestressed tendon ratio, the longitudinal reinforcement ratio and the stirrup reinforcement ratio on the hysteretic behaviour and seismic characteristics of the prestressed concrete bridge pier have been obtained with the fiber model analysis method. The analysis show some results about the prestressed concrete bridge pier. Firstly, greater prestressed tendon ratio and more longitudinal reinforcement can lead to more obvious pier's hysteresis loop "pinching effect," smaller residual displacement, and lower energy dissipation capacity. Secondly, the greater the stirrup reinforcement ratio is, the greater the hysteresis loop area is. That also means that bridge piers will have better ductility and stronger shear capacity. The results of the research will provide a theoretical basis for the hysteretic behavior analysis of the prestressed concrete pier [13].

This paper discusses the parametric study of two different cross-sections of box-girder for same loading conditions to find the most economical cross-section. The design standard of India, IRC was followed in design of Box-girder superstructures subjected to IRC class AA loading. Analysis is carried out using the MIDAS Civil Software which is based on finite element method of analysis. A $30 \mathrm{~m}$ span length and $10 \mathrm{~m}$ width bridge deck is being analysed in this work. The result shows the multi cell box girders are costlier as compare to the single cell box girder, when the loading and support condition were kept same for both the cross-section. It shows that the single cell prestressed Concrete box girder is most suitable and economical cross-section for 2 lane Indian national Highway bridges [14].

The objective is to minimize the total cost in the design process of the bridge system considering the cost of materials like steel, concrete, tendons etc. For a particular problem the design variables considered for the cost minimization of the bridge system, are depth of girder, various cross sectional dimensions of the girder, number of tendons. MATLAB R2010a software is used.. The proposed cost optimization approach is compared with an existing project which leads to a considerable cost saving while resulting in feasible design. From graph, for conventional and optimal design consideration; it shows 


\section{Nanomedicine \& Nanotechnology Open Access}

that overall cost of structure can be reduced by using optimization technique with stability [15].

In this study, the prestressed concrete box beam bridge structure is meant and linear, non-linear, time history analysis is performed. The bridge structure is subjected to completely different IRC loadings. The study shows however variations within the bridge pure mathematics, damage scenarios, member properties and bridge continuity affect the redundancy of the superstructure. Specifically, Time History Analysis is used to investigate the sensitivity of the structure to variations in various parameters including: a) boundary conditions; b) damage of prestressed members and damage scenarios; c) member capacity; d) non-linear effect. SAP 2000 V15 is used in this analysis work.

The result concludes that among the both linear and non-linear analysis the deflection changes up to $30 \%$ $40 \%$ periodically. Comparison between linear and nonlinear results shows that the results obtained from nonlinear analysis is however more higher than linear analysis but they are quite much more accurate [16].

In the gift work, analysis and style of beam has been done, considering 2 completely different over layer pipes namely HDPE and corrugated Bright metal pipes. These protective cover pipes are accustomed notice the economic resolution of style of multi-cell box beam. CSIbridge standard software system has been used for closing analysis. Various losses that occur thanks to completely different phenomena like elastic shortening, Creep, shrinkage, friction and wobble loss are thought of. It concludes that style the planning the look of PSC multicell beam performed is found to be a cheap design corresponding important bending moment and shear forces developed thanks to varied load mixtures as per IRC specifications as compared with the planning of comparable span configuration mistreatment I girders with Cast In Situ (C.I.S) deck slab [17].

In this work, 2 sections of post-tensioned box beam of same span length, loading and dimensional properties ar compared. The cross-sections are Rectangular and Trapezoidal. As per IRC:6-2000 live load combination for one lane of sophistication 70R and for one lane of sophistication a kind loading square measure thought of for this analysis. According to this analysis the quadrangle section of beam is subjected to less shear force and bending moment than that of rectangular section for same loading, span and dimensional properties due to its geometry. Tensional moment developed in quadrangle section is additionally less as compared to it of rectangular section [18].

In the gift study skew bridge examination with the conventional bridge for skew angle ten, 20, 30, 40, 50 is considered. The finite part analysis is dole out for single span, two span and three span deck for dead load and moving load (IRC class 70R) loading using software SAP2000 ver.14. The results square measure conferred in terms of displacement, bending moment and shear force.

The study shows that the deflection decreases with increase in skew angle in 2 or 3 span skew block whereas just in case of single span deflection will increase with increase in skew angle. This shows that the result of deflection is a lot of in single span skew deck blocks because the stiffness of slab is a smaller amount. Bending moment has reduced with increase in skew angle underneath load in single, two and three spans deck. But underneath moving load there's slight reduction in bending moment up to $20^{\circ}$ then exaggerated for $30^{\circ}$ and any reduced for $40^{\circ}$ skew angle solely on single span deck. The magnitude of shear force has slightly reduced with increase in skew angle underneath load in 2 and 3 span deck, it absolutely was ascertained that the magnitude had increased under moving load [19].

In this work, beam recurved in set up with quadrangle crosswise is taken into account. The analysis is carried underneath the load, super obligatory load, load of IRC category A self-propelled vehicle and prestressed load. Box girder used is of various radius of curvature and length of span, material properties and cross sectional form is unbroken constant.

In this study it is observed that as radius of curvature of box girder increases the deflection, bending moment, torsion and longitudinal bending stress along the span decreases. There is no \{significant|vital|important\} variation in bending moment, deflection longitudinal bending stresses \{under|beneath|underneath|below\} DL+SIDL, moving load and prestressed load for specific span length with different radii. The torsional moment \{increases|will increase greatly with decrease in radius of curvature \{under|beneath|underneath|below\} all loading conditions. There is more variation in torsion with span radius below $100 \mathrm{~m}$ therefore it's better to avoid such sharp curves and if they are unavoidable then structural changes to cross sectional dimension, must be made to stabilize the box girders [20]. 


\section{Nanomedicine \& Nanotechnology Open Access}

In this work, SAP2000 is used in caring out linear analysis using 4-node thin shell element of single cell post-tensioned concrete box girder with simply supported ends. A comparative study carried on longitudinal

\{transverse|cross|transversal|thwartwise|crosswise\}

bending stress, shear stress, torsional shear stress both by SAP2000 software and manual calculation. A typical $40 \mathrm{~m}$ rectangular concrete $\{$ box girder|box beam|beam bridge \{is considered|is taken into account \} in analysis \{and design|and style\}. IRC specifications \{class|category\} \{aone|ace|A-one|crack|first-

rate|super|tiptop|topnotch|tops|superior\} lane, \{class|category\} A-two lane and IRC 70R-one lane loading \{are|ar|area unit|square measure\} \{considered|thoughtabout|thought of in analysis \{and design|and style\}. The result concludes that the percentage|the share|the proportion\} \{difference|distinction\} between results from \{simple|straightforward|easy\} beam theory and finite \{element|part|component\}

\{method|technique|methodology\} for longitudinal analysis is $\{2 \mid$ two $\mid$ a pair of $\} .95 \%$ for top slab and $-6.85 \%$ for bottom slab. Shear stresses obtained at the junction of webs and flanges are more compared with stresses in web portions. Inclined webs of \{box girder|box beam|beam\} behaves structurally \{better|higher\} \{based on|supported\} force flow condition. Trapezoidal \{box girder|box beam|beam\} offers \{more|additional|a lot of resistance to shear generated [21].

In this project, the behavior of \{box girder|box beam|beam\} bridges with \{respect to|reference to|regard to|relation to|relevance|relevancy\} support reaction shear force, bending moment, torsion and axial force under standard IRC Class AA loading is done. The \{box girder|box beam|beam $\}$ bridges models \{analyzed|analyzed\} by finite \{element|part|component\} \{method|technique|methodology\}

\{using|exploitation|victimization|victimisation|mistreatm ent $\}$ SAP2000. Bridge deck of $\{60 \mid$ sixty $\} \mathrm{m},\{80 \mid$ eighty $\} \mathrm{m}$ and $\{100 \mid$ one hundred|a hundred\} $\mathrm{m}$ \{are|ar|area unit|square measure\} \{considered|thought-about|thought of\}. Analysis results bending moment, shear force, displacement and torsion are extracted along with stress variations along different section for different cases are discussed and max deflection of box girder and stress behavior in box girder due to pre-stressing force is studied in this paper work [22].

In this study they tries \{to compare|to match|to check\} the cost|the value|the price $\}$ of the \{superstructure|structure|construction\} of bridges for $20 \mathrm{~m}$ and $25 \mathrm{~m}$ span. Four \{types of |sorts of|kinds of|styles of|varieties of|forms of the superstructures \{are|ar|area unit|square measure\} used for the study \{purposes|functions\}, namely; reinforced concrete $\mathrm{T}$ beam, reinforced concrete I- beam, prestressed concrete I-beam and steel composite I-beam. For the analysis fand design|and style\} \{purposes|functions\}, the loading standards of the Indian Road Congress (IRC) have been adopted. The study \{is done|is completed|is finished\} by \{calculating|calculative|conniving|scheming|shrewd|hard \} \{the cost|the value|the price\} \{associated with|related to \{various|numerous|varied\} stages of construction \{and service|and repair\} life and these are|ar|area unit|square measure\}, the basic material cost, transportation cost, placement/launching cost, maintenance cost and the lifecycle cost. It describes the cost|the value|the price\} on the basis|the idea|the premise\} of considering \{various|numerous|varied\} support conditions, constituent materials, casting/fabrication methodologies etc. to reach at best economical option including the lifecycle cost. It includes Basic Material Cost, Placement/Launching Cost, and Lifecycle Cost [23].

In this thesis, analysis and style of prestressed concrete bridges (Deck block, T-Girder and Box Girder) ar applied exploitation IRC: 112-2011. Post tensioned beam of thirty $\mathrm{m}$ span and seven. $5 \mathrm{~m}$ of dimension is taken into account during this analysis. SAP 2000 is used for the mathematical modeling. M50 grade of concrete and Fe415 steel is employed. Different span to depth quantitative relations (L/d) ratio ranging from fifteen to nineteen and totally \{different|completely different\} span to depth ratios (L/d) ar thought of. The result concludes because the depth of beam decreases, the prestressing force decreases and no of cables decreases. Because of prestressing, more strength of concrete is utilized and also well governs serviceability [24].

Present study includes parametric study on prestressed concrete girder bridge superstructure. Three different spans of $30 \mathrm{~m}, 35 \mathrm{~m}, 40 \mathrm{~m}$ are considered and length to span ratio is $14,15,16$ respectively.

After analyzing Box Girder and Tee Girder with CSI Bridge 2014 it conclude that as the span increases the box girder shows better results for selecting between both girders. By the numbers of prestressing cables required to resist the load, box girder required less cables. Loads are almost similar in both the girders but for $40 \mathrm{~m}$ span box 


\section{Nanomedicine \& Nanotechnology Open Access}

girder is governing section, but is has its own flaws too. It is having a complex shuttering and it's required more skilled labor to carry out that task but overall Box girder is preferable [25].

In this work, box Girde Bridge of single cell type is analyzed using SAP2000 V14. Three shapes rectangular, trapezoidal and circular are considered and the curvature of the bridges varies only in horizontal direction. Moving load of IRC class A tracked vehicle is applied and Static analyses under different loading conditions are performed.

From this study it is concluded that the trapezoidal section is superior to circular and rectangular section. Among rectangular, circular and trapezoidal box girders of all radii, the torsion is maximum for circular box girders and least for trapezoidal box girders. B. The trapezoidal section is the stiffest section and the most stable among the three sections.

\section{Conclusion}

The study shows the comparative study between different shapes of PSC Box Girder Multi Cell (3 Cell) Bridge like (1) Vertical side, (2) Slopped side, (3) Clipped side, (4) External Girder with Radius, (5) Max. Slopped. The loading of IRC category - A is applied and analysis is dole out victimisation IRC - 112 (2011). For the modeling and analysis purpose CSI Bridge (V - 2017) is employed. As it could be a review paper, so the final results and detailed work, graphs, diagrams etc. will be discussed in final paper.

\section{References}

1. Olivier B, Marc B (1999) Deflection Monitoring of Prestressed Concrete Bridges Retrofitted by External Post-Tensioning. IABSE Symposium-Rio de Janeiro.

2. Barr PJ, Eberhard MO, Stanton JF (2001) Live load distribution factors in prestressed concrete beam bridges. Journal of Bridge Engineering 6(5).

3. Barr PJ, ASCE M, Stanton JF, Eberhard MO (2005) Effects of Temperature Variations on formed, Prestressed Concrete Bridge Girders. Journal of Bridge Engineering@ASCE.

4. Chen C, Kaiyin Z (2011) Research on temperature field and temperature stress of prestressed concrete

Selvan V and Gobinath RS. Pre-Stressed Concrete Box Girder Multi Cell (3-Cell) Bridge of Different Shapes a Comparative Study: A Review Paper. Nanomed Nanotechnol 2019, 4(3): 000167. girders. IJ Intelligent Systems and Applications 1: 2532.

5. Vikash K, Pramod KS, Maiti PR (2012) Comparative study of prestressed steel-concrete composite bridge of different span length and girder spacing. International Journal of Recent Engineering analysis (IJMER) 2(5): 3917-3922.

6. Byungik YK, Kamal M, Seungyeol L, Kenneth L (2012) Optimization of Post-Tensioned Box Girder Bridges with Special Reference to Use of High-Strength Concrete Using AASHTO LRFD Method. Advances in Civil Engineering.

7. Maroliya MK (2012) Comparative Study Of Flexural Behavior Of Reinforced Concrete Beam And Prestressed Concrete Beam. International Journal of Engineering Research and Applications (IJERA) 2(6): 230-233.

8. Amit S, Savita M (2013) Comparative Study of the Analysis and style of T-Beam beam and box beam Superstructure. International Journal of Research in Engineering \& Advanced Technology (IJREAT) 1(2).

9. Durgesh CR, ASCE M, Srinaganjaneyulu K, Tripti P (2013) Strengthening of block Action in transversal Direction of broken Deck of Prestressed box beam Bridge.

10. Vishal UM, Gore NG, Salunke PJ (2014) Analysis and style of Prestressed Concrete Girder. International Journal of Emerging Science and Engineering 2(9): 43-47.

11. Rajamoori AK, Vamsi KB (2014) Design of PreStressed Concrete T-Beams. International Journal of Scientific Engineering and Research (IJSER) 2(8): $37-$ 42.

12. Hui-li W, Feng GQ, Qin SG (2014) Hysteretic Behavior of Prestressed Concrete Bridge Pier with Fiber Model. The Scientific World Journal.

13. Mayank C, Saleem A (2015) Design and Analysis of Prestressed Concrete box beam by Finite component methodology (4 Cells Cell). International Journal of Civil and Structural Engineering analysis 3(1): 413421.

14. Bhawar PD, Wakchaure MR, Nagare PN (2015) Optimization of Prestressed Concrete Girder. IJRET: 


\section{Nanomedicine \& Nanotechnology Open Access}

International Journal of analysis in Engineering and Technology 4(3): 634-639.

15. Paval B (2015) Analysis of Multi-Cell Prestressed Concrete Box-Girder Bridge. International Journal of Engineering Technology Science and Research IJETSR $3(4)$.

16. Chetan T N, Achar MM, Lakshmi K (2015) Analysis and style of Multi Cell Post-Tensioned PSC Box Girder. IOSR Journal of Mechanical and Civil Engineering (IOSR-JMCE) 12(4): 56-64.

17. Payoshni M, Shilpa K, Savita L (2015) Comparison of Rectangular and Trapezoidal sections of Post Tensioned Box Girder. International Journal of Scientific \& Engineering analysis 6(12): 195-197.

18. Pranathi R, Karuna S (2015) Comparative Study on Traditional and Skew Bridge of PSC Box Girder. IJRET: International Journal of analysis in Engineering and Technology.

19. Jefeena S, Kashif QI, Reji PM (2015) Parametric Study of Behaviour of Box Girder Bridges Under Different Radius of Curvature. International Journal of Science and analysis IJSR.

20. Ajith Kumar R, Dattatreya JK (2015) Study on the Structural Behavior and style of a Typical Single Cell
Post Tensioned Concrete box beam Bridge. Journal of applied science and Environmental Technology 2(11): 1-6.

21. Punil Kumar MP, Shilpa BS (2016) Dynamic analysis of box girder bridges. International analysis Journal of Engineering and Technology (IRJET) 3(7).

22. Natraj S, Devgan NP, Kalra AM, Surinder P (2016) Effect on Economy on Successive Increase in the Span of Bridges. Proceedings of the $2 \mathrm{~d}$ International Conference on Civil, Structural and Transportation Engineering (ICCSTE'16), Ottawa.

23. Phani Kumar $\mathrm{CH}$, Babu SVVK (2016) Analysis and Design of Prestressed Box Girder Bridge by IRC: 1122011. International Journal of Constructive analysis in applied science (IJCRCE) 2(2): 1-10.

24. Sanket P, Umang P (2016) Comparative Study of PSC. Tee Girder and PSC. Box Girder. IJSTE - International Journal of Science Technology \& Engineering 2(11).

25. Karthika S, Asha V (2016) Parametric Study on Behavior of Box Girder Bridges with Different Shape Based On Torsion. International Journal for Research in Applied Science \& Engineering Technology (IJRASET) 4(7). 